\title{
LA VOZ DE LOS INSTRUMENTOS \\ EN MANOS DE LOS JUGLARES
}

\author{
Carlos Villanueva \\ Universidad de Santiago de Compostela \\ carlos.villanueva@usc.es
}

\begin{abstract}
Resum
Lo profano y lo religioso en la imago musicae medieval conviven y se alternan con la naturalidad que la retórica y los sermones de la época nos dictan: equilibrio y armonía de la más pura esencia boeciana, por un lado, y desequilibrio y transgresión en el mensaje de la música que los juglares transmiten. La Iglesia no ha dejado nunca de condenar aquellas prácticas en el templo y en la calle, o la intromisión de lo profano dentro de la liturgia, aunque, por la propia curiositas — como recalca S. Moralejo-y por la fascinación de la transgresión que la Musica instrumentalis genera, también fueron merecedores de tener su catequesis en piedra. Los juglares del refectorio del Palacio de Gelmírez (s. XIII) ofrecen un buen modelo para estudiar y ejemplificar aquellas interferencias de uno y otro nivel moral, así como una estampa de contenido realista al tiempo que simbólico.
\end{abstract}

\section{Paraules clau}

Juglares, Palacio de Gelmírez, instrumentos medievales, icnografía musical.

\begin{abstract}
The voice of the instruments in the hands of minstrels. The profane and the religious in medieval imago musicae coexist and alternate with the naturalness prescribed by the rhetoric and sermons of the time: on the one hand, there is the balance and harmony of the purest Bothian essence, and on the other hand, the imbalance and transgression in the message of the music transmitted by the minstrels. The Church has never ceased to condemn those practices in the churches and in the street, or the intrusion of the profane into the liturgy, though — as is stressed by S. Moralejo — both the curiositas and the fascination raised by the transgression of Musica instrumentalis were also worthy of having their catechism in stone. The minstrels in the refectory of the Gelmírez Palace (I3th century) provide a good model to study and exemplify those interferences of moral levels as well as its realistic and symbolic contents.
\end{abstract}

\section{Keywords}

Minstrels, Gelmírez Palace, medieval instruments, musical iconography. 
I. Existe un tópico entre los estudiosos de instrumentos que venimos leyendo y escuchando desde hace ańos; y no es otro que formular, sin mayor explicación o argumentos, que una imagen musical de contexto profano (unos juglares del comedor de Gelmírez o de la iglesia de Santiago de Carrión de los Condes, pongamos por caso) [Fig. I] suministrarán mejor y más limpia información que otra representación de contexto religioso; por el hecho de que cuanto más se implique y penetre el instrumento en un guión teológico más pesada será su carga conceptual y, por tanto, residual a la hora de limpiarlo e interpretarlo. ${ }^{1}$

Así, hemos tenido que debatir frecuentemente sobre la supuesta gran calidad de los instrumentos del Palacio de Gelmírez, frente a los del Pórtico de la Gloria; habiéndose llegado a la conclusión, no siempre aceptada unánimemente, de que aquellos proceden de los del Maestro Mateo, son más anecdóticos e imprecisos a la hora de trasladarlos a la madera, y están sujetos a un fuerte programa simbólico que hasta hace poco ni se contemplaba. ${ }^{2}$

2. En cambio, he de reconocer que la reiteración de estos instrumentos y la posibilidad de poderlos relacionar con una escuela escultórica de la calidad de la de Mateo, nos permite estudiarlos y compararlos, entre sí y con los demás, analizando elementos de jerarquización en su ubicación, enriqueciéndolos con excursos teológicos sobre la Trinidad o la Concordia, o bien con detalles estructurales y ornamentales que nos animan a formular una unidad de criterio en cuanto a su diseño y a sus posibles técnicas de construcción. ${ }^{3}$ Forman parte, además, del

I La cruzada contra el empleo de los instrumentos en el templo emprendida por J. McKinnon desde su tesis (1965), soportada por lecturas bíblicas y de los padres de la Iglesia, prendió en varias líneas de investigación que poco tenían que ver con el uso, formato de los instrumentos y otras derivaciones simbólicas; todo ello se vio favorecido (y enriquecido académicamente) con las nuevas orientaciones historicistas desde el mundo anglosajón que, afortunadamente, van remitiendo. Cfr. J.W. Mckinnon, The Church Fadhers and the musical instruments, Ph.d. Columbia University, I965; para un estado de la cuestión con amplia bibliografía Cfr. C. Villanueva, "Musicología e interpretación musical", Revista de Musicología, xv (2005), p. I5.

2 Las mejores referencias sobre estas discusiones las encontramos en J. López-Calo (ed.), Los Instrumentos del Pórtico de la Gloria: su reconstrucción y la música de su tiempo, A Coruña, I993; también en C. Villanueva (coord.), El Pórtico de la Gloria: Música, Arte y Pensamiento, Santiago de Compostela ( $2^{a}$ edición), i9ir, con aportaciones de S. Moralejo, E. Romero Pose, J. LópezCalo, S. Jensen y F. Luengo; también en C. Villanueva (ed.), El sonido de la piedra. Encuentro sobre instrumentos en el Camino de Santiago, Santiago de Compostela, 2005, especialmente en las aportaciones de M. Castiñeiras, M. C. Gómez, Ch. Rault, y R. Álvarez; y, sobre el refectorio de Gelmírez, en L. Pérez (ed.), Instrumentos de corda medievais, Lugo, 200o, con trabajos de $\mathrm{CH}_{\text {. }}$ Rault, F. Luengo, J. Wright y R. Yzquierdo Perrín.

3 Las aproximaciones entre las figuras teológico-musicales de Joaquín de Fiore y los ancianos del 
riquísimo instrumentario enciclopédico de mediados del XIII presente en pórticos de iglesias, en manuscritos, y en poemas y crónicas.

3. Como bien indica Serafín Moralejo, "con la fachada románica esculturada, asistimos a una extroversión del santuario, que lo es también de lo suntuario; la decoración del edificio se vuelca hacia el exterior, hacia los espacios sociales rurales o urbanos, hacia el mundo. Su enfático despliegue figurativo acusa un acento e intención similares a los que se reconocen en el coetáneo desarrollo de una hagiografía y de una épica en lengua vulgar"; 4 lo que también se reconocen en las manifestaciones del folklore o de los cuentos populares.

Esa búsqueda de los espacio exteriores rurales o urbanos conlleva normalmente una rara cohabitación de instrumentos de nivel popular, culto o religioso, que a veces resulta difícil de categorizar y hasta de justificar, a menos que acudamos a explicaciones que no nacen de los propios instrumentos ni de su uso, sino de argumentos que hemos ido incorporando a nuestro discurso: por ejemplo, los instrumentos se intercambian, pasan de un nivel a otro por razones de moralidad, de catequesis o sin una razón especial: sencillamente, por llamar la atención, precisamente por la fascinación que el juglar conlleva. ${ }^{5}$

A modo de ejemplo, sobre la estampa de un clérigo (en el artesonado de la catedral de Teruel) con traje pontifical está tocando un laúd; [Fig. 2] se trate o no de un retrato, nos indica Moralejo que la imagen de un clérigo-juglar no había de escandalizar en la época, por excepcional que fuera, y tampoco hay que verla como necesariamente paródica. ¿Qué es David sino un juglar al que la clerecía más rigurosa debió presentar como una paradoja moral? "Un tan declarado

Pórtico de la Gloria ofrecen variados caminos de reflexión de enorme interés para la interpretación real y simbólica de los instrumentos, tal como se hacía en los conventos de la época; Cfr. C. Villanueva, "El Psalterium decem chordarum y otros dibujos musicales de Joaquín de Fiore", en El sonido de la piedra, p. I79; ÁNGEL Medina ha tratado con gran acierto este tema y sus perspectivas morales, especialmente, en "Virtudes, vicios y teoría del canto en la época del Maestro Mateo", en El Códice Calixtino y la música de su tiempo (J. López-Calo y C. Villanueva, eds.), A Coruña, Fundación Barrié, 200I, p. 75.

4 S. Moralejo: "Artes figurativas y artes literarias en la España medieval: románico, romance, roman", en Patrimonio artístico de Galicia y otros estudios. Homenaje al Prof. Dr. Serafin Moralejo. [tomo II], Santiago, Xunta de Galaicia, 2004, p. 56.

5 Aporta Moralejo la anécdota del predicador inglés que, para atraer al público, se vestía de juglar y comenzaba a cantar canciones populares y juglarescas; cuando tenía al público suficiente se presentaba y empezaba su predicación; "Tan original y precursora pastoral tenía su equivalencia plástica en las galas seculares — con conspicua presencia de motivos histriónicos- con que se revisten tantas portadas románicas, en su voluntad de captar la atención del espectador", S. Moralejo, "Artes figurativas y artes literarias...", p. 58 ss. 
enemigo de la juglaría como San Bernardo reconocía en la danza histriónica de David un ejemplo de humildad, de degradación voluntaria ante Dios" ${ }^{6}$

$\mathrm{Ni}$ que decir tiene que tal género de ambigüedades era, sino buscado conscientemente, al menos, aceptado o asumido por los clérigos responsables de tales programas iconográficos como recurso para hacer más atractivo y familiar el mensaje cristiano. ${ }^{7}$

Y es que a la hora de gestionar la fascinación no hay principios preestablecidos. Hay personajes, como el Rey David, que encierran en sí mismos varios niveles de recepción: según esté pecando, arrepintiéndose, dirigiendo a sus levitas en el Templo, o presentándose como el ascendiente de Cristo en el Árbol de Jesé... [Fig. 3] Las posibilidades de intercambio instrumental son múltiples y la carga simbólica de los instrumentos presentes muy variada: según el espacio, el guión, la escuela, el material, la orden religiosa, el taller, o el público receptor.

Me viene bien para mi argumentación aquella cita del Evangelio transcrita en la regla benedictina con glosas de San Agustín: Todo el que se exalta será humillado y el que se humilla será ensalzado (Lc. I8, 8-I4): nada mejor para definir el estado moral de un personaje que rebajarlo o elevarlo de nivel mediante la representación de un instrumento no habitual del nivel social o moral que representa. Nada más eficaz para la sorpresa — como indica M. Castińeiras - ${ }^{8}$ que la presentación de David tocando el crwth, al lado de danzarines y malabaristas que se contonean alocadamente [en la imagen del tonario-tropario de Auch, tantas veces reproducido]. [Fig. 4] O en la estampa de San Miguel do Monte (Chantada-Lugo), donde aparece un rústico David violista con una danzarina y un percusionista percutiendo un "pandeiro", en una composición tenida hasta no hace mucho como puro e intrascendente "mester de juglaría". [Fig. 5]

4. En algunos casos, mediante la correspondiente moralización, los motivos profanos se convierten en vehículos portadores de un pensamiento religioso. Pero otras veces — como bien recalca Moralejo— "quizá no haya que buscarles otra trascendencia que la de ser un excipiente para excitar y reconducir la curiositas de los fieles", algo que la Iglesia experimentó con la música litúrgica en todo tiempo y lugar: en dramas litúrgicos y paralitúrgicos, canzonetas, villancicos, pastoradas, oratorios, representaciones, danzas, etc.; "tal género de ambigüedades era, sino buscado conscientemente, al menos, aceptado o asumido por los clérigos respon-

6 S. Moralejo, "Artes figurativas y artes literarias...”, p. 56.

7 Ibidem.

8 M. Castiñeiras, "Concierto del Apocalipsis y el arte de los Caminos de Peregrinación”, en El sonido de la piedra, p. II9.

${ }_{9}$ Cfr. Los comentarios a esta estampa de S. Moralejo, "Artes figurativas y artes literarias...", p. 56. 
sables de tales programas [iconográficos o musicales] como recurso para hacer más atractivo y familiar el mensaje cristiano", copiando los formatos del teatro vivo y del sonido de la calle ${ }^{\mathrm{TO}}$.

5. Topográficamente, en las representaciones de instrumentos del medioevo hay como dos polos o niveles, que podríamos establecer tomado de las sólidas teorías boecianas tan presentes en todos aquellos presupuestos teóricos vigentes durante siglos, algo que hemos analizado al hablar de la enseñanza en el Císter, tema también tratado por varios autores: ${ }^{\text {II }}$

- Por un lado, el polo positivo: la bondad de la música reside en la armonía, el orden, la proporción y se desarrolla en lo sagrado, con la belleza y la virtud; con especial referencia a determinados instrumentos y contextos.

- El polo opuesto sería el desorden, la ausencia de armonía, el ruido, el exceso..., algo que ya los sermones de la época relacionan con lo demoníaco, el pecado y lo profano; pero no exento de fascinación en esa invasión de los niveles, como podemos comprobar en paralelo en los cantos, tropos, secuencias, farsas y demás variantes de los músicos mendicantes, goliardos y otras especies callejeras tan fascinantes. La exégesis de ciertos textos medievales sobre música nos obliga, por tanto, a trabajar con las distintas esferas morales antes perfiladas. Según refiere A. Medina, Honorio, un teólogo del siglo xir, transcribe un diálogo en el que taxativamente se afirma que los juglares no tienen ninguna esperanza de salvación, dado que en todo son ministros de Satanás:

- (D) Habent spem joculatores?

- (M) Nulla: tota namque intentione sunt ministri Satanae. ${ }^{\text {I2 }}$

6. También habrá que hacer otros distingos. En los ágapes, junto al acto de comer, músicos y juglares amenizan el festín entre el servicio de cada plato, o, por el contrario, rematan el festejo con su sesión musical de coplas en torno al vino y el amor (lo leemos en muchas narraciones de según qué cronistas y según con qué intenciones). En cualquier caso, el Rey Sabio nos dice de sus juglares que "saben portarse con cortesía, ante un público distinguido, cantando canciones hechas por otros, tocando instrumentos musicales o declamando poesías narrativas"; de hecho ahí los tenemos: impecables, refinados y contenidos, tañendo y cantando delante de la Virgen en la Cantiga I20. [Fig. 6]

io S. Moralejo, "Artes figurativas y artes literarias...", p. 58.

i Cfr. M. Castiñeiras, "Concierto del Apocalipsis...”, p. i27; C. Villanueva, "El Psalterium decem chordarum...", p. I79; o A. Medina, "Vicios y virtudes...", p. 75.

I2 Apud A. Medina, "Vicios y virtudes...", p. 85. 
Lo podemos corroborar en la escena que se recrea en la $5^{\mathrm{a}}$ ménsula del Palacio de Gelmírez (juglares de pié tocando viola, arpa y doble flauta) [Fig. 7] porque hay en la instantánea, aparte de la contención y el decoro, algo más: como nos diría Meyer Schapiro, cierto trasfondo simbólico y teológico, sobre lo que reflexionaremos en el practicum.

Ciertamente, esta ménsula no representa a juglares histriónicos, como en otros casos; y de hecho hay cierta correspondencia con imágenes sacras de contexto gallego (en concreto el músico de la izquierda que afina la viola, con la gestualidad ya vista en el Pórtico de la Gloria; o el que tañe la doble flauta, similar al del Pórtico del Paraíso de la catedral de Ourense). Hay, no obstante, elementos significativos como tocar de pié, moviéndose, y precisamente con esos instrumentos más propios de la juglaría. Manuel $\mathrm{Nún} \mathrm{z}^{\mathrm{13}}$ ha ofrecido nuevas lecturas e interpretaciones, como veremos en la segunda parte de nuestra disertación.

7. Podría referirme, porque viene al caso, a Maricarmen Gómez, cuando, en diversas ocasiones, nos habla de la vinculación de la música a las enseñanzas del Trivium y el Cuadrivium como un nuevo nivel de interrelación del pensamiento musical ${ }^{14}$; o a la cita de Francisco Rico, que ha querido ver, incluso, en la portada de la Iglesia de Ripoll, realizada a mediados del siglo xII, un reflejo de las teorías boecianas del monje Oliva, pues al lado izquierdo de la fachada se representa un concierto de música instrumental compuesto por un David sedente presidiendo un cuarteto de viento, cuerda y percusión, reflejo del Salmo I50, 2-5:

Alabad al Señor al son de las trompetas,
Alabadle con el salterio y con la cítara.
Alabadle con los tímpanos y las danzas,
Alabadle con las cuerdas y con la flauta.
Alabadle con los címbalos resonantes. ${ }^{15}$

$\mathrm{Y}$ es que el tema que veíamos de David con sus juglares ante los is escalones del Templo de Jerusalén, en donde se reunía con sus Levitas para entonar los salmos penitenciales, es repertorio y motivo que guarda una estrecha relación con las peregrinaciones en general y a Santiago en particular, como he tratado en otra

i3 M. Núñez Rodríguez, El refectorio del Palacio de Gelmírez, Santiago de Compostela, Consorcio de Santiago, 1996.

I4 También hemos de referir, más concretamente para nuestro presente estudio, las ideas de M. Castiñeiras sobre las enseñanzas del Quadrivium en los monasterios, "Concierto del Apocalipsis...", p. I29.

I5 F. Rico, Signos e indicios de la Portada de Ripoll, Barcelona, 1976 (reed. Figuras con paisaje, Madrid, pp. I07-I76), apud M. CAstiñeIras, "Concierto del Apocalipsis...”, p. I3I. 
ocasión en mi estudio sobre la música en el Camino de Santiago: ${ }^{16}$ la puerta de las Platerías de la catedral compostelana, precedida de 15 escalones, acoge ahora a David sedente, tañendo una viola mientras aplasta con saña la cabeza de la serpiente. ${ }^{17}$ [Fig. 8]

\section{Practicum I. El refectorio de Gelmírez [Fig. 9]}

Me van a permitir que desarrolle un breve practicum de todas las ideas hasta ahora vertidas, tomando como referencia y espejo los músicos del Refectorio del Palacio de Gelmírez, espacio construido unos sesenta años después del Pórtico de la Gloria y cuyos instrumentos hemos estudiado, analizado y hasta construido en diferentes etapas. ${ }^{18}$

Presenta ángeles antropomorfos en las claves de las dos bóvedas centrales sosteniendo el sol y la luna, lo que nos está hablando de un espacio "humano", terrenal, bajo la bóveda celeste, donde cualquier representación instrumental comporta un contexto profano en sus aplicaciones musicales, aunque pueda tener, como veremos, enseñanzas y aplicaciones teológicas. En la clave del Pórtico de la Gloria, por el contrario, está el Cordero, pues "el espacio celeste no precisa del sol o la luna, pues la ilumina el Cordero místico”, según indica sagazmente S. Moralejo. ${ }^{19}$

\section{Estado de la Cuestión ${ }^{20}$}

Para López Ferreiro, estamos ante la imagen de un salón-comedor objetivo, con reyes, músicos y muchas viandas, aunque la estampa simbólica del banquete va

i6 C. Villanueva, "Música y peregrinación: imagen en piedra para una catequesis", en $V$ Congreso Internacional de Estudios Jacobeos, Santiago, 2000, y "Música y músicos en el Camino de Santiago", en Los Caminos de Santiago. Arte, Historia, Literatura, Zaragoza, 2005.

I7 Cfr. para una mejor comprensión de las fachadas de la catedral M. NúñEz, A la búsqueda de la memoria: los tres pórticos mayores de la basilica de Gelmírez, Madrid y Santiago, $201 \mathrm{I}$.

I8 Cfr. nota 2.

I9 S. Moralejo, "La imagen arquitectónica del Pórtico de la Gloria", en Il Pellegrinaggio a Santiago de Compostela e la letteratura jacopea: atti del Convegno Internazionale di Studi, Perugia, settembre 1983; a cura di G. SCALIA, Centro Italiano di Studi Compostellani, Perugia, 1985, p. 37.

20 Tomamos el breve estado de la cuestión que aportamos del libro de M. NuÑEZ, El refectorio del Palacio de Gelmírez... , pp. 3I ss, junto con otras referencias específicas recogidas en el detallado artículo de R. Yzquierdo Perrín, "Os pazos arcebispais de Santiago na historia da Arte", en Instrumentos de corda medievais...", pp. I9 ss. 
más allá de la mera imagen del homaneje al Monarca. ${ }^{21}$ Para Vicente Lampérez, ${ }^{22}$ contamos, además de las viandas, con una bendición de la mesa, músicos amenizando un convite Real, y los ángeles que concurren con los principios morales de la fe y de la caridad (no hagas a los otros lo que no hagas para ti, dice una de la cartelas angélicas), virtudes que se le suponen al Monarca, como representante que es de Dios en la tierra, y, al tiempo, una suerte de homenaje por parte del arzobispado al monarca.

Sánchez Cantón y Pita Andrade ${ }^{23}$ vienen a decir que es la representación del banquete de Alfonso IX y dońa Berenguela, o bien la crónica de la peregrinación de Fernando III y Beatriz de Suavia; en todo caso un banquete objetivo e histórico, con viandas de Galicia y amenizado por la mejor orquesta posible de las tierras de Compostela.

Serafín Moralejo da un paso más, indicando que la profanidad (y la supuesta crónica de sociedad) es meramente pretextual, con inspiración en los músicos apocalíticos del Pórtico; un ángel a quien se le confía la lectura "edificante" y las cartelas en las que se indicaría la referencia al banquete celestial: representación, pues, simbólica, estableciendo así una relación entre el plano sagrado y profano: las imágenes se representan como expresión de la trascendencia de los actos y realidades materiales; convites terrenales evocan convites celestiales, y la música de los juglares y trovadores se trasciende en la que acompaña a las místicas bodas del Cordero (el Esposo, la invitación a la boda, las vírgenes necias y prudentes...). La valoración teológica aquí experimentada se ofrece en simbiosis con lo que representa la figura del monarca, o vicario de Cristo. ${ }^{24}$

El profesor Yzquierdo Perrín, ${ }^{25}$ estudioso del maestro Mateo y de su escuela, ofrece una amplia síntesis de los diferentes palacios arzobispales compostelanos y de su evolución, desde su primera piedra hasta llegar a hoy, con su aportación en el tema del simbolismo y un buen número de referencias bibliográficas sobre la materia, además de la contextualización de los instrumentos en clave tanto comparatista como simbólica.

2i Cfr. A. López Ferreiro, Historia de la S.A.M. Iglesia de Santiago de Compostela, vol. v, Santiago de Compostela, Seminario Conciliar, 1902, p. 217.

22 Cfr. V. Lampérez y Romea, "El antiguo Palacio Episcopal de Santiago de Compostela", B.S.E.E., XXI (1913), p. 42.

23 E. Sánchez Cantón y J. M. Pita Andrade, Los retratos de los reyes en España. Barcelona, Omega, 1948, pp. 33 ss., apud M. NúNEEz, El refectorio del Palacio de Gelmirez..., p. 4I.

24 Cfr. S. Moralejo, "O refectorio do Pazo de Xelmírez", en O Pórtico da Gloria e o seu tempo, Santiago, Xunta de Galicia, 1988, p. 51, apud M. NúŃEZ, El refectorio del Palacio de Gelmírez..., p. 2I.

${ }_{25}$ R. Yzquierdo Perrín, "Os pazos arcebispais de Santiago na historia da Arte”, en Instrumentos de corda medievais..., pp. 19-94. 
El profesor Manuel Núñez avanza un paso más en la interpretación con su monografía sobre el refectorio del Palacio de Gelmírez, ${ }^{26}$ obra muy documentada y repleta de citas y reflexiones y que, en el terreno que nos ocupa, prolongará contenidos, posteriormente, en su artículo sobre David músico. ${ }^{27}$

En cualquier caso, y por razones prácticas, me subiré al relato del profesor Núñez, aprovechando su conducción, para ir haciendo mi propia reflexión sobre los instrumentos del llamado salón de Gelmírez, que es en realidad obra del Arzobispo Don Juan Arias: "esta iconografía sobre una promesa de matrimonio — dice Núnez-, al tiempo que da la fe del reconocimiento por parte del Don Juan Arias y de su cabildo, es la prueba de un gesto de fidelidad-homenaje al rey por parte de un funcionario".

Y sigo con la cita contextual del profesor Compostelano:

Tal valor explicativo (moralizante y ejemplarizante) impone la intricada labor de resaltar, no tanto lo profano de este programa, — aunque sea obligado punto de arranque — como los recursos que invocan el prestigio y la superioridad moral de aquella monarquía castellano leonesa que no cuenta con la condición de ungida. Junto a estos resortes, el mejor garante de la equidistancia con una escena de banquete al uso, es, sin duda, el protagonismo que adquiere la música en las dos terceras partes de la obra; sin duda el medio más idóneo para acceder a la verdad revelada, por encima del lenguaje oral..$^{28}$

A mi entender, y en síntesis, una estela del programa del Pórtico de Mateo altamente sofisticada en su simbolismo pero desgastada en sus perfiles e imágenes con el paso de los años; como suele ocurrir con los remakes de grandes obras.

Habíamos visto la $5^{a}$ ménsula con músicos en pie tocando instrumentos juglarescos, en el tramo que Núnéz llama el de la realidad (del acontecer, dice concretamente).

El siguiente tramo lo denomina el espacio simbólico que arranca con la ménsula $7^{\text {a }}$, [Fig. Io] en donde, con la imagen del organistrum próxima a la del Pórtico de la Gloria, señala la representación de la concordia de la Antigua y la Nueva Ley mediante el instrumento trinitario por excelencia como piedra angular e imagen de Cristo ${ }^{29}$. Ahora, en la interpretación de M. Núnez, se prefigura la unión de la realeza veterotestamentaria (i.e. el rey David) y la nueva realeza (el nuevo David

26 M. NuñEz, El refectorio del Palacio de Gelmírez...

27 M. NuñEz, "David, el canticum y la iucunditas en el siglo XII", en El sonido de la piedra, p. 89. 28 M. Nuñez, El refectorio del Palacio de Gelmírez..., p. 2 I.

29 Cfr. el desarrollo e interpretación de los círculos trinitarios de Joaquín de Fiore en paralelo al organistrum del Maestro Mateo, en C. Villanueva, "El Psalterium decem chordarum...", p. I79; sobre su estructura y construcción cfr. CH. Rault, "La Reconstrucción del organistrum", Los Instrumentos del Pórtico de la Gloria..., pp. 383-42I. 
que es el monarca), con todas las alegorías posibles de la auctoritas divina sobre la potestas temporal. Acompaña a los músicos coronados un juglar tocando una viola sobre la rodilla (da gamba).

La ménsula $\mathrm{n}^{\circ}{ }_{13}$, [Fig. II] presenta cuatro músicos tocando 3 violas de arco y una cítola: los dos centrales están "coronados"; los de las esquinas son juglares, con instrumentos tipológicamente más juglarescos, si cabe. Núñez vuelve a hablarnos de la relación del nuevo y del viejo David, como lo había hecho ante el organistrum (un símbolo de la alianza perpetua entre Dios y su pueblo): “imagen del nuevo David que habrá de aglutinar la acción política y la religión, para expresar mejor la alianza entre Dios y su pueblo; o mejor, la no distorsión entre el orden cristiano y el orden temporal". ${ }^{30}$ Un análisis, a mi entender, que va más allá de lo que en realidad se representa: propiamente un desgaste del mensaje visual de los modelos del Portico de la Gloria a los que imita (en concreto la gestualidad de aquellos dos de los ancianos que tañen sendas violas en $8 / \mathrm{o}$ gigas en concreto, instrumento esencialmente teológico, como yo mismo estudié a partir de los dibujos de Joaquín de Fiore). ${ }^{3 \mathrm{I}}$ Evidente desgaste de imagen como ocurre en la catedral de Orense, o en la fachada occidental de la colegiata de Toro. En relación a esta ménsula, Francisco Luengo habla como luthier de violas híbridas (tomadas como solución constructiva de las cítolas, que también aparecen en el Comedor tocadas siempre por juglares). ${ }^{32}$

Me interesa especialmente la ménsula $9^{\text {a }}$, [Fig. I2] no sólo por el vínculo más estrecho que manifiesta con el taller del Maestro Mateo en la presencia de tres músicos coronados especialmente significativos: el que afina su viola moviendo el puente, como el anciano $\mathrm{n}^{\circ} 2$ del Pórtico; el que señala con el dedo la redoma; y el que sostiene un arpa-salterio (o rota-salterio según denominación de Ch. Rault), un instrumento que merece una reflexión más detenida.

Coincido con Rault al considerar el arpa-salterio, junto con el organistrum, como uno de los instrumentos más significativos e intensos del conjunto; raramente en uso "religioso" en aquella época y que ha dado formas y contextos de lo

30 M. Nuñez, El refectorio del Palacio de Gelmírez..., p. iI7.

3I C. Villanueva, "El Psalterium decem chordarum..."; resulta muy sugerente, y refuerza todo nuestro discurso, la propuesta, ofrecida por Ch. Rault, de considerar la viola en forma de 8 (también llamada giga) como una síntesis "prêt-à-porter" típicamente cisterciense del organistrum, pero con todos sus valores teológicos latentes: las tres cuerdas trinitarias, tendidas entre alfa y omega, los círculos entrelazados, etc.; su carácter estrictamente litúrgico en las todas representaciones, su solemnidad y estatismo a tocarla (frente a la movilidad de la viola oval trovadoresca); y jerárquicamente siempre ensalzado (como ocurre en el Pórtico, a un lado y a otro del organistrum, auténtica piedra angular) y en contextos de alabanza, Cfr. $\mathrm{CH}$. Rault, "Instrumentos de arco musulmanes y cristianos, sus influencias recíprocas", en Los Sonidos de Pórtico, p. 305.

32 F. Luengo, "Os instrumentos musicais na Compostela medieval", en Instrumentos de corda medievais..., p. 155 . 
más variado, tanto en la escultura como en los dibujos y pinturas. Del más de un centenar de representaciones esculpidas de la rota salterio recogidas y estudiadas por Rault, ${ }^{33}$ un tercio se refieren al Rey David, proporción que aumenta en las fuentes manuscritas, reservadas para los eruditos. Cuando la visión es en una Iglesia, para que la gente los contemple directamente esculpidos en la piedra, suele ocupar un lugar preferente y bien centrado, cerca de la clave del arco, o en lugar muy visible. ${ }^{34}$

Alcanzan, no obstante, una cuarta parte del total las representaciones bufonescas o de animales tocando la rota (burros, cabras, etc.), [Fig. I3] con lo que, a mi entender y como analizábamos al comienzo de nuestra exposición, se busca, precisamente trayendo una rota, el mayor contraste posible; el mayor sinsentido, sorpresa y regocijo, al mostrar groseramente las vastas patas del animal haciendo sonar el instrumento trinitario más célebre: el de la perfecta triangularidad cósmica, el que acostumbraba a tañer David salmista o alguno de los 24 ancianos del Cántico Nuevo. "Ese uso ligado a la música religiosa se mantuvo probablemente más allá del siglo XII, pero bastante pronto volvemos a hallar nuestro instrumento muy apreciado en contextos menos austeros; así, en II4O aparece en la recepción de personajes por los juglares o [tocado por] los peregrinos ante el Apóstol" 35 [descripciones que hay que tomar con sumo cuidado porque muchas veces se trata de meros espejos enciclopédicos, como refleja Berceo o se muestra en el sermón Veneranda Dies, del Códice Calixtino:

Causa alegría y admiración contemplar los coros de peregrinos al pie del altar del venerable Santiago en perpetua vigilancia: los teutones a un lado, los francos a otro, los italianos a otro; están en grupos, tienen cirios ardiendo en sus manos; por ello toda la iglesia se ilumina como el sol en un día claro. Cada uno con sus compatriotas cumple individualmente con maestría las guardias. Unos tocan cítaras, otros liras, otros tímpanos, otros flautas, caramillos, trompetas, arpas, violas, rottas británicas o galas, otros cantando con cítaras, acompañados de diversos instrumentos, pasan la noche en vela; otros lloran sus pecados, otros leen los salmos, otros dan limosna a los ciegos... ${ }^{36}$

$33 \mathrm{CH}$. Rault, "Ensaio sobre un instrumento de música medieval desaparecido", en Instrumentos de corda medievais..., p. 223; Cfr. también C. Villanueva: "El Arpa-salterio en España a través de las representaciones en la piedra de los siglos XII y XIII: un ensayo de reconstrucción”, en Alfonso XEl Sabio impulsor del arte, la cultura y el humanismo: el arpa en la Edad Media española, M. R. CALvoManzano (ed.). Madrid, I998, p. 269.

34 Ch. Rault, "Ensaio sobre un instrumento", p. 238.

35 CH. Rault, "Ensaio sobre un instrumento", p. 3 Iо.

36 Liber Sancti Iacobi. Codex Calixtinus, trad. A. Moralejo, C. Torres y J. Feo, Santiago de Compostela, I95I; ed. revisada por J. J. Moralejo y M. J. García Blanco, Santiago de Compostela, 2004 . 
También aparece en lugar preeminente en las miniaturas de las cantigas de Alfonso X, ahora como "juglares a lo divino".

No parece, por las narraciones y las crónicas, un instrumento adecuado para representaciones festivas y ruidosas; tocada con plectros de madera y de pluma la rota más bien está asociada con el sonido suave y la dulzura del arpa. "La asociación de estos instrumentos en un contexto de ejecución musical —dice Rault - es tal vez significativo, fuera del parentesco instrumental que los une, de su parecido, incluso de la semejanza de las técnicas de interpretación de estos dos instrumentos, hasta el punto de no resultar nada extraño ver al mismo músico interpretar el uno y el otro".$^{37}$ En general aparece el arpa salterio relacionada con clases altas y géneros de prestigio (tropos, chanson, lai) y asociado a Alejandro el Grande, a Tristán o al Rey David. Aunque también, como dije, aparece en manos de los juglares o animales en géneros menores o ínfimos: quizá, precisamente, para subrayar el contraste a modo de caricatura.

\section{CONCLusiones}

Una de las sólidas ideas que concierne a la música de la Edad Media es la oposición constante entre dos maneras, radicalmente opuestas, de utilizarla:

a) Si, por una parte, permite la música calmar el espíritu y elevar el alma a través de la práctica esencialmente religiosa del canto, siendo capaz de expresar las verdades inmateriales, es también el soporte y señal de la perversión, de la orgía a través de las canciones paganas, o como soporte de la danza.

b) Por otra parte, la Iglesia no ha dejado de condenar dichas prácticas, intentando, sobre todo en el siglo XII, alejar de sus atrios y claustros a los juglares y a los músicos, cuyo status tendía constantemente a elevarse en calidad y reconocimiento, hasta el punto de desbordar su función y entrometerse en la música de la Iglesia (lo que de hecho sucede, en las representaciones litúrgicas y populares condenadas por los sínodos, los concilios y las propias cartas pastorales).

c) Pero, a pesar de todo ello, el clérigo medieval parece envidiar en secreto el poder de convocatoria del juglar, temeroso de la competencia que su tosca e irreverente literatura pueda suponer para la palabra de Dios. Y es que los aspectos negativos también son merecedores de tener su catequesis en piedra, de ahí los animales tocando; o ciertas representaciones juglarescas que son auténticas fábulas morales: por ejemplo aquella imagen del burro tocando el harpa-salterio y que, además, está cantando con su genuina voz de burro: una de las categorías

37 CH. Rault, “Ensaio sobre un instrumento...”, p 310. 
vocales denostadas por San Isidoro (en edición de Gerbert), a la hora de buscar candidatos para el coro:

Detestamos las voces histriónicas, gárrulas, alpinas o montunas, silbantes, relinchantes, como de rebuzno asnar, así como las [voces] mugientes y baladoras como de rebaños, o las afeminadas, y prohibimos en nuestros coros toda falsedad, jactancia o novedad de las voces; pues más llevan a la vanidad y a la estulticia que a la religión..$^{8}$

Y estas han sido mis reflexiones sobre "La voz de los instrumentos en manos de los juglares" que espero les haya agradado tanto como a mi estar hoy aquí en este estupendo simposio: Joglars, Ministrils, Actors.

38 Apud A. Medina, "Virtudes, vicios y teoría del canto...", p. 75. 


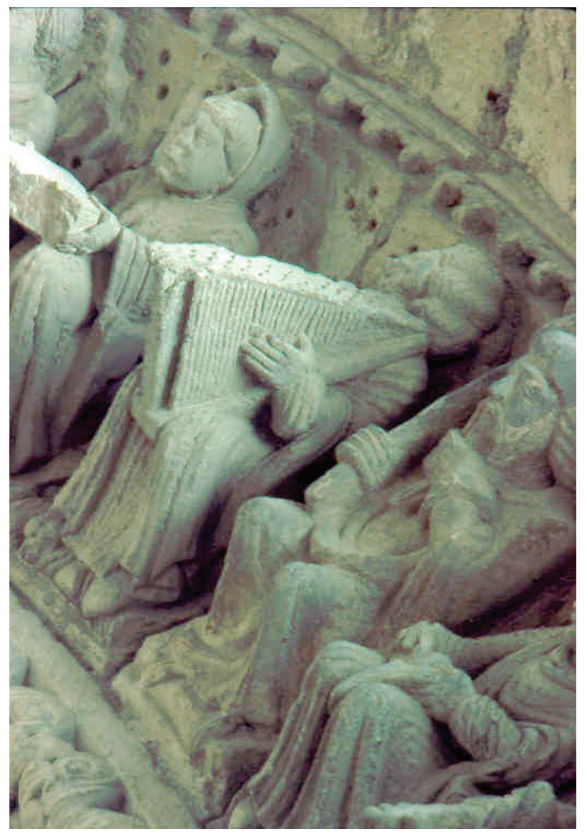

I. Carrión de los Condes, Iglesia de Santiago.

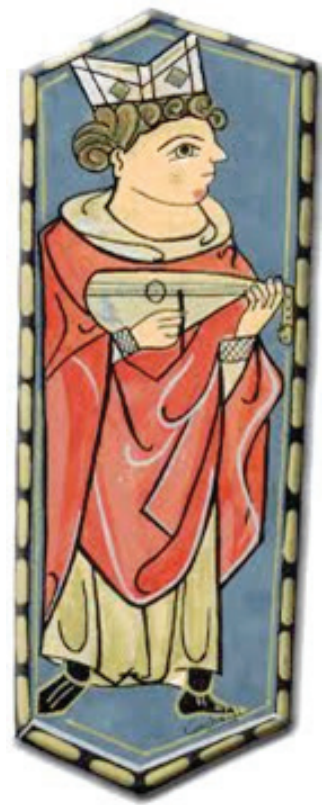

2. Catedral de Teruel, artesonado. 


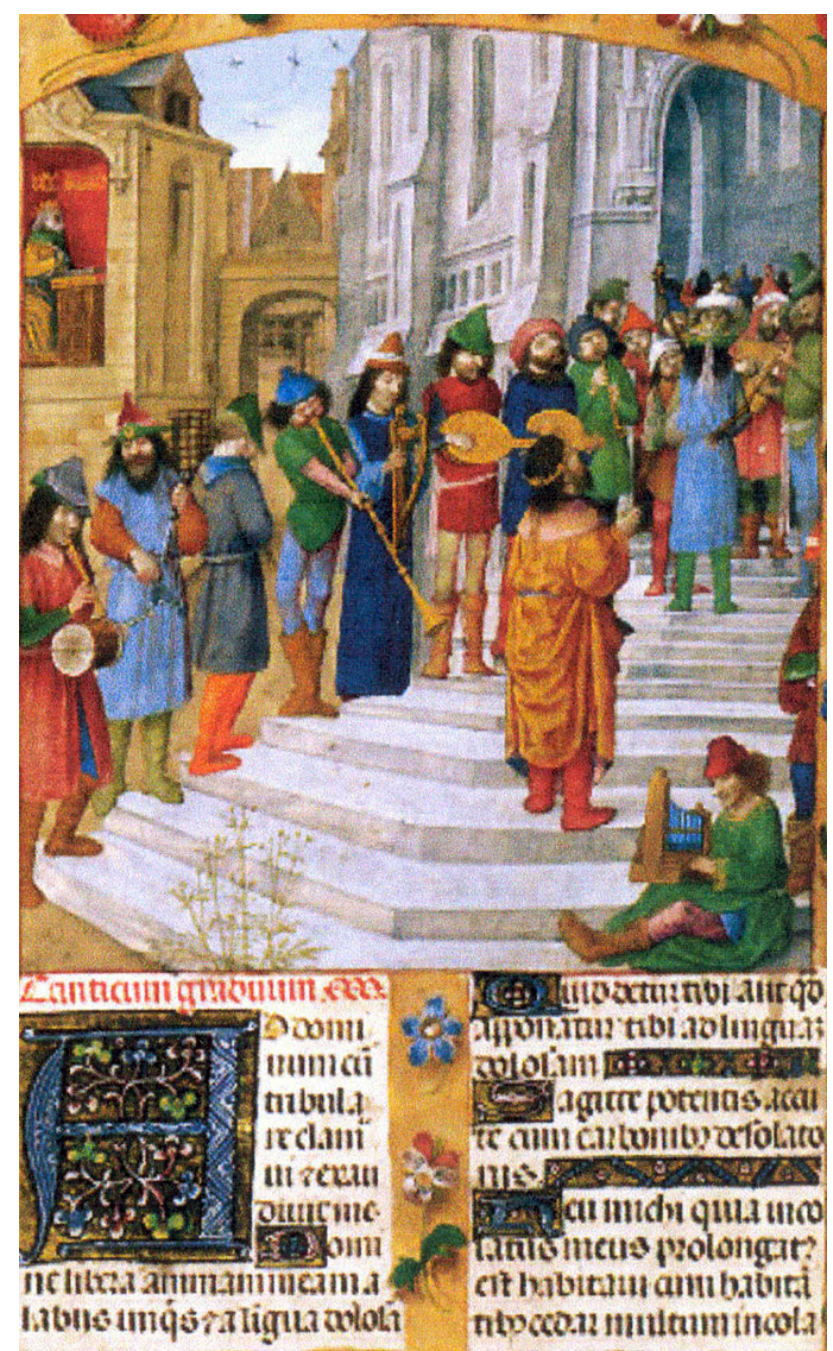

3. Breviario de Isabel la Católica, s. xv. 


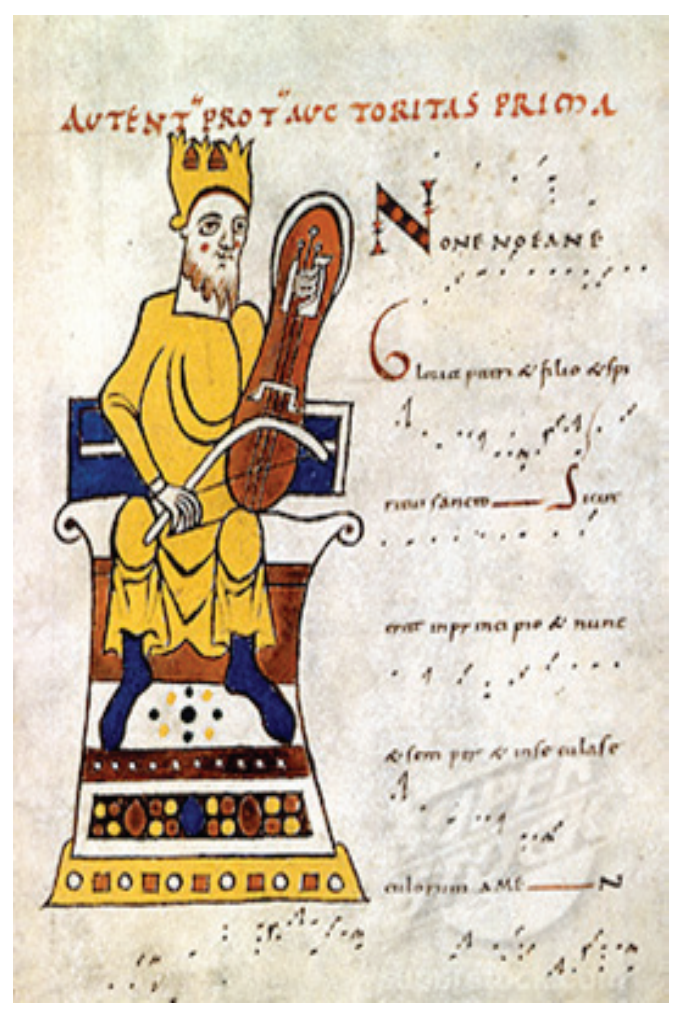

4. Tropario de Auch.

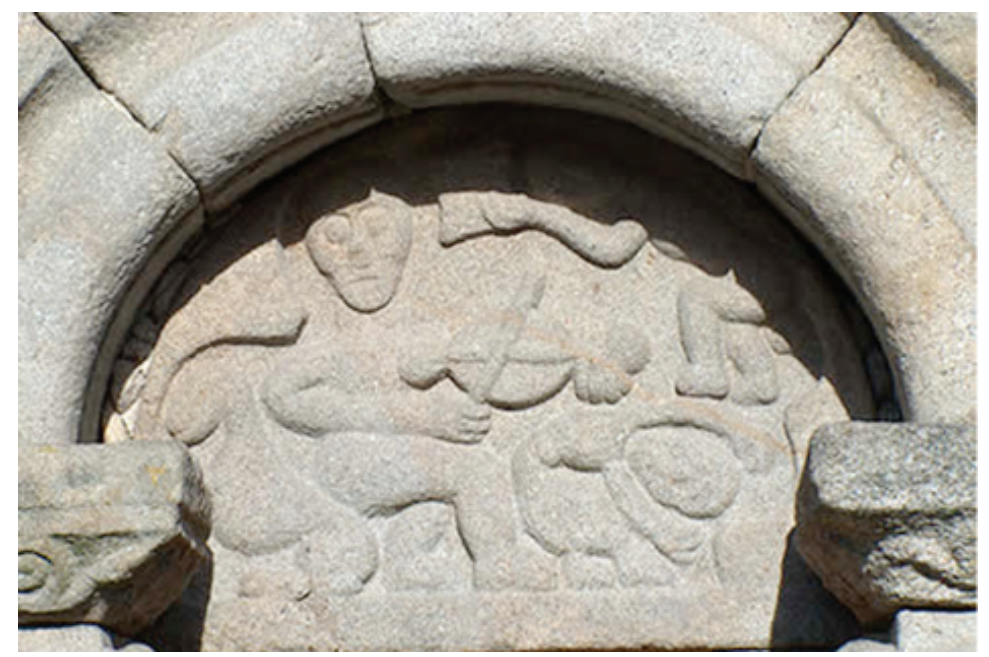

5. San Miguel do Monte, Chantada (Lugo). 


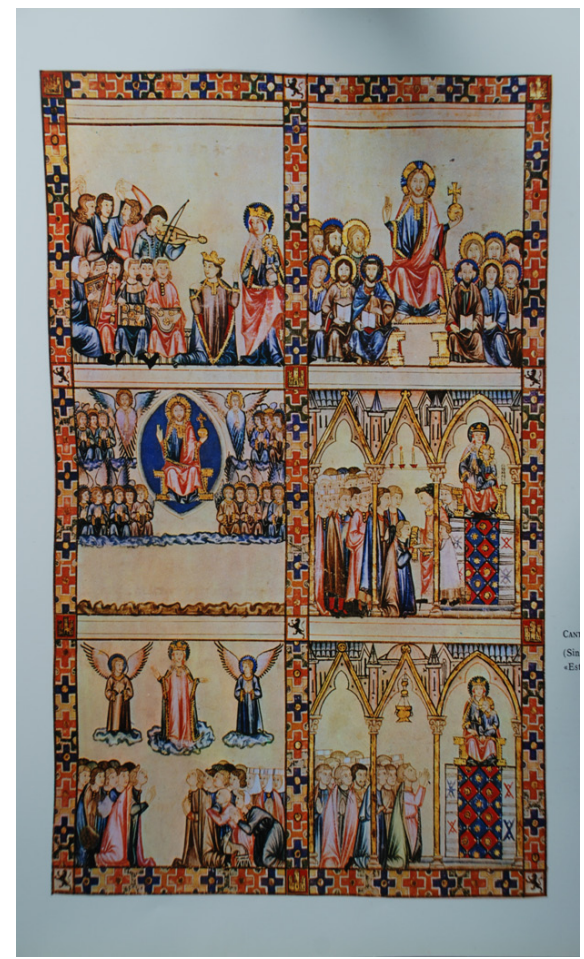

6. Cantiga I20, Códice Rico, El Escorial.

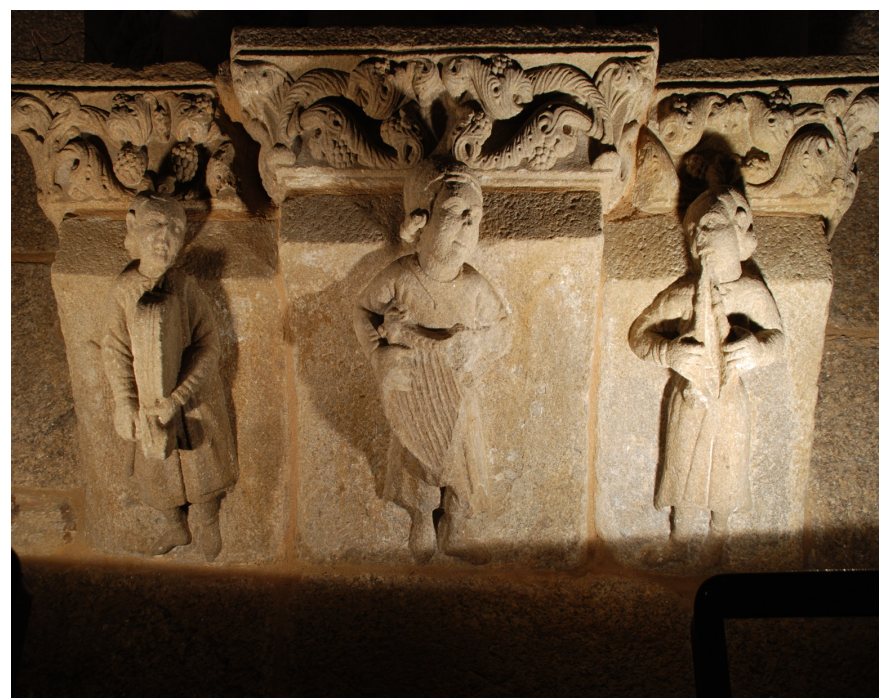

7. Ménsula $n^{\circ} 5$ del Palacio de Gelmírez (foto P. Carpintero). 


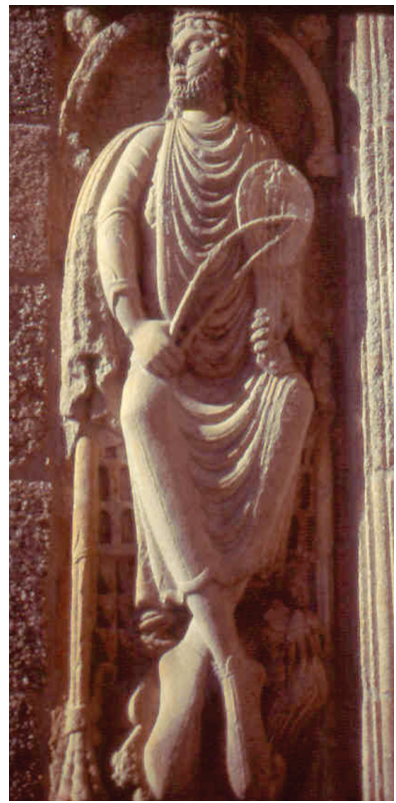

8. David de Platerías, Santiago de Compostela.

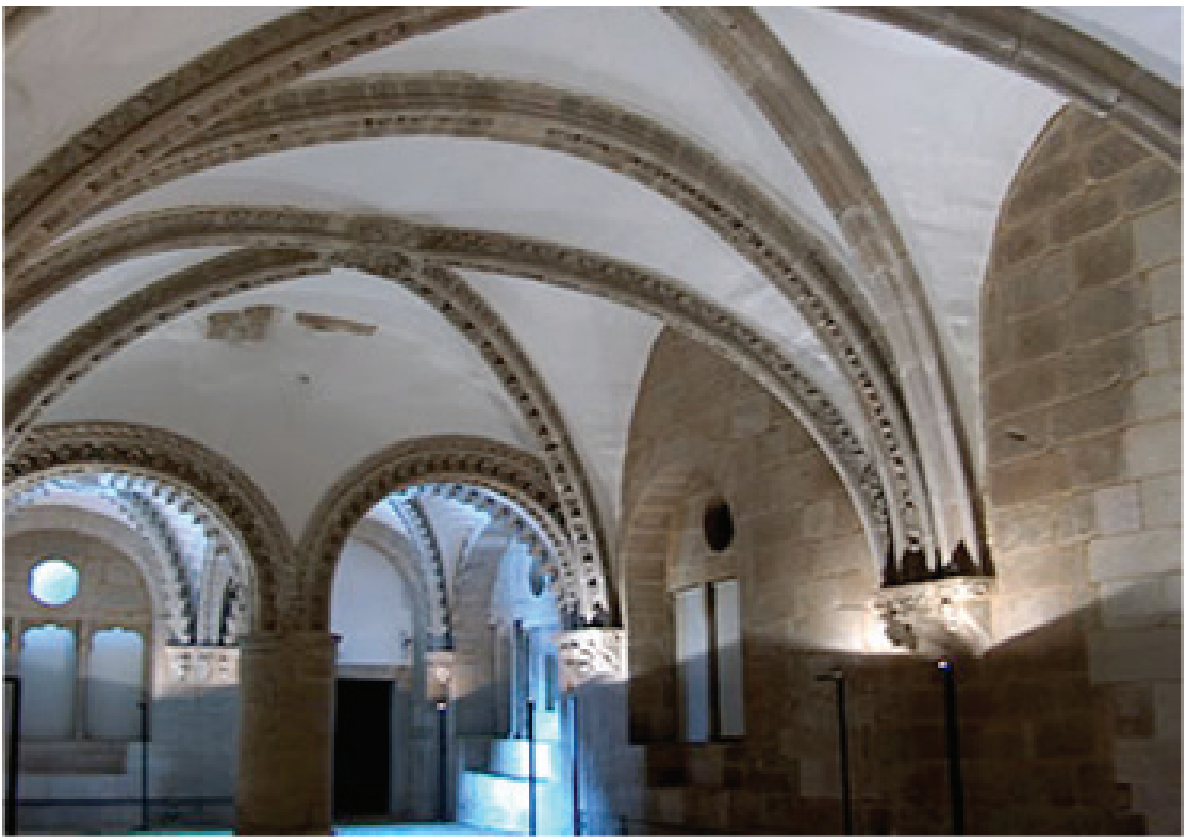

9. Palacio de Gelmírez, Refectorio. 


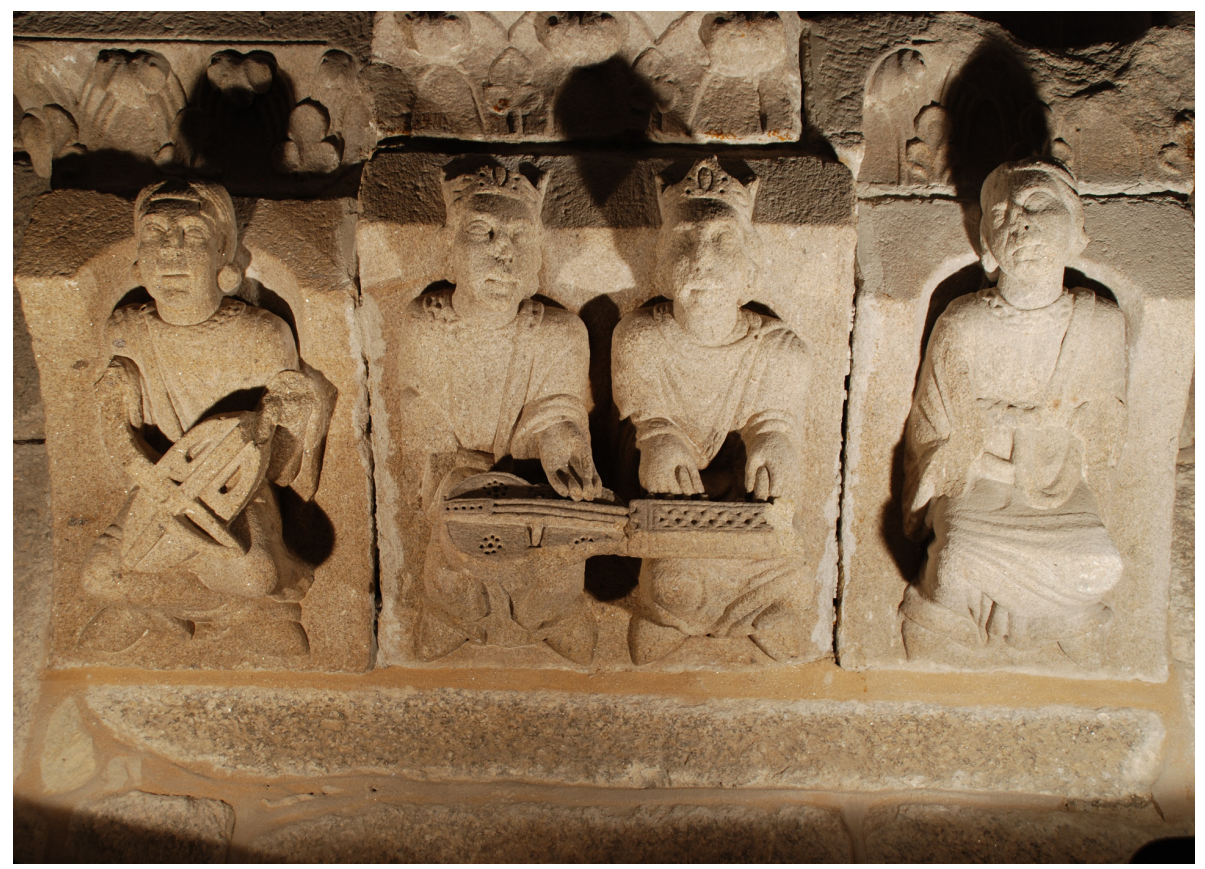

Io. Ménsula no 7 del Palacio de Gelmírez (foto P. Carpintero).

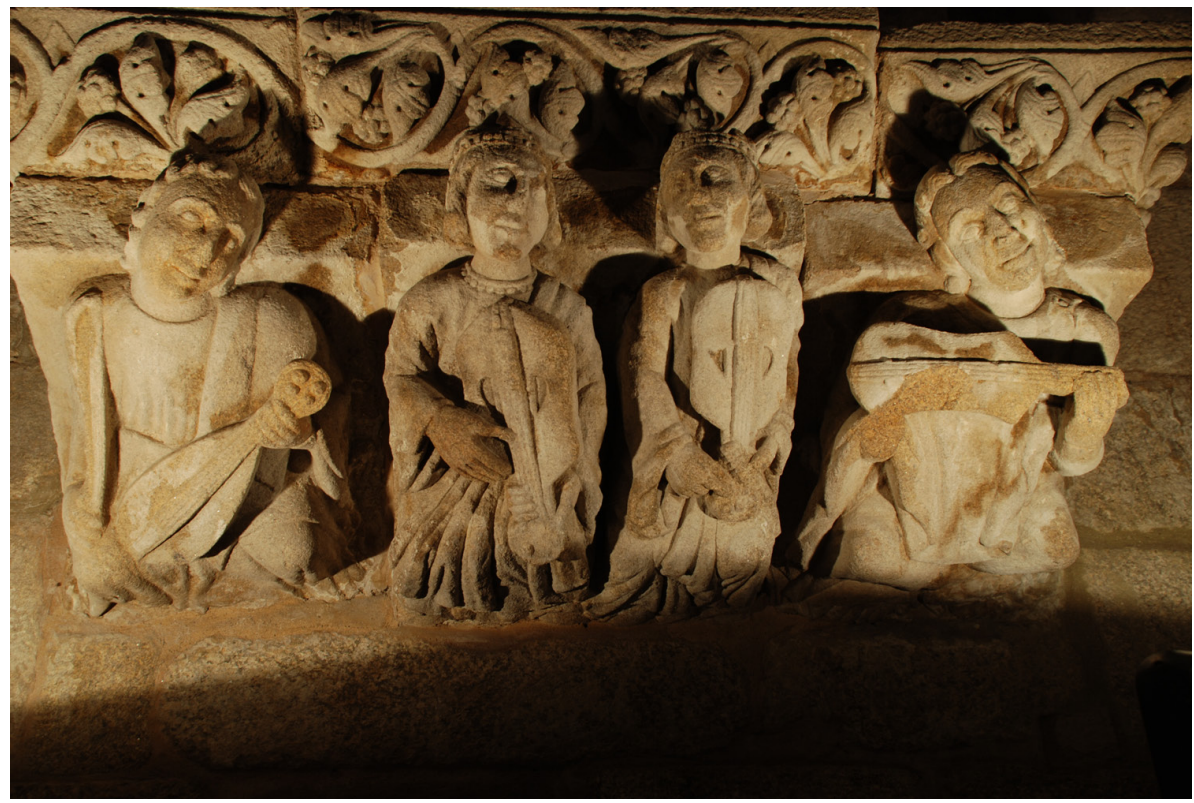

II. Ménsula no ${ }^{\circ} 3$ del Palacio de Gelmírez (foto P. Carpintero). 


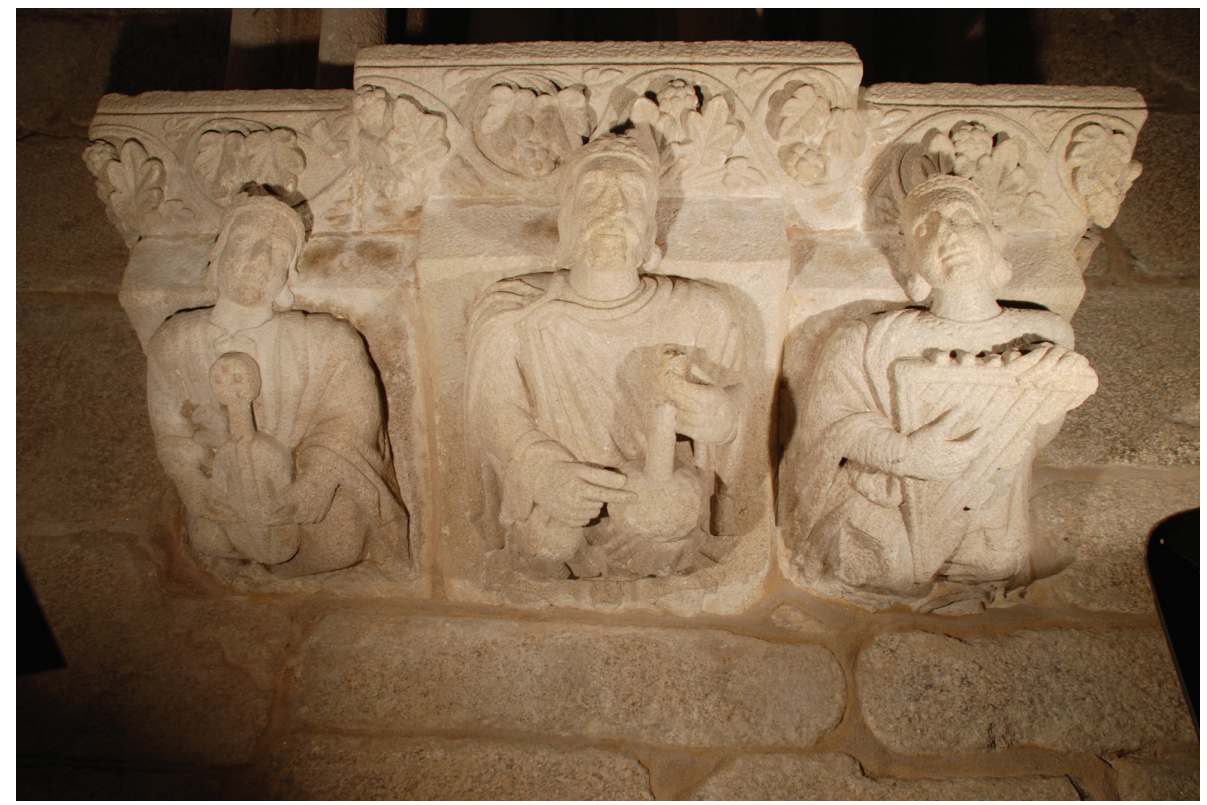

I2. Ménsula no 9 del Palacio de Gelmírez (foto P. Carpintero).

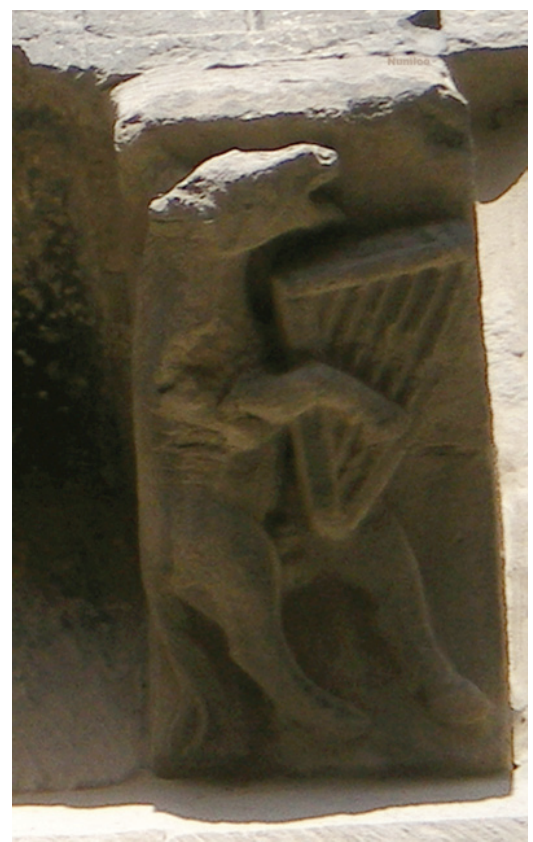

I3. Burro tocando el arpa-salterio, Catedral de Tudela. 